\title{
Peroxisome proliferator-activated receptor- $\gamma$ agonist-mediated inhibition of cell growth is independent of apoptosis in human epidermoid carcinoma A431 cells
}

\author{
QIAN LI, YU-SHENG PENG, PING-JIAO CHEN, MENG-LEI WANG, CAN CAO, HAO XIONG, \\ JINGZHANG, MING-HUA CHEN, XUE-BIAO PENG and KANG ZENG
}

Department of Dermatology, Nanfang Hospital, Southern Medical University, Guangzhou, Guangdong 510515, P.R. China

Received June 28, 2016; Accepted August 23, 2017

DOI: $10.3892 / \mathrm{ol} .2018 .8136$

\begin{abstract}
Evidence suggests that peroxisome proliferator activated receptor- $\gamma$ (PPAR- $\gamma$ ) acts as a tumor suppressor in multiple types of cancer; however, the role of action of PPAR- $\gamma$ on human epidermoid carcinoma is unclear. The present study investigated the effects of a PPAR- $\gamma$ agonist, rosiglitazone, on human epidermoid carcinoma cell growth using the A431 cell line. The effects of rosiglitazone on cell viability and proliferation were evaluated with MTS and $\left[{ }^{3} \mathrm{H}\right]$ thymidine incorporation assays. The effects of rosiglitazone on the cell cycle and apoptosis were analyzed by flow cytometry, and western blotting. It was identified that rosiglitazone inhibited A431 cell proliferation in a dose-dependent manner, increased the proportion of cells in the G1 phase, but did not affect apoptosis. Consistently, there was a significant decrease in the expression of cell proliferation-associated proteins, including cyclin D1, cyclin-dependent kinase (Cdk)2 and Cdk4 in A431 cells treated with rosiglitazone. This decrease was rescued by a selective antagonist of PPAR- $\gamma$ or specific PPAR- $\gamma$ small interfering RNAs. However, the ratio of B-cell lymphoma 2 (Bcl-2) to Bcl-2 associated $\mathrm{X}$ protein, which is associated with cell apoptosis, was not affected by these treatments. The data of the present study suggest that the PPAR- $\gamma$ agonist rosiglitazone inhibits human epidermoid carcinoma cell growth through regulating the expression of the cell cycle-associated proteins, and that this effect is independent of apoptosis.
\end{abstract}

Correspondence to: Dr Kang Zeng, Department of Dermatology, Nanfang Hospital, Southern Medical University, 1838 North Guangzhou Road, Guangzhou, Guangdong 510515, P.R. China E-mail: kang_zeng@sina.cn

Abbreviations: PPAR- $\gamma$, peroxisome proliferator activated receptor- $\gamma$; SCC, squamous cell carcinoma; SD, standard deviation; PI, propidium iodide

Key words: PPAR- $\gamma$, rosiglitazone, human epidermoid carcinoma, cell growth

\section{Introduction}

Squamous cell carcinoma (SCC) is a common type of skin cancer. Although SCC primarily occurs in areas of the skin that are frequently exposed to sun, it may occur on all areas of body, including the mucous membranes and genitals $(1,2)$. It is estimated that 700,000 incident cases of SCC were diagnosed in the United States in 2012 (3). Understanding the mechanism of SCC, and developing novel and effective therapies are required.

Peroxisome proliferator-activated receptor- $\gamma$ (PPAR- $\gamma$ ) activation has been demonstrated to inhibit cell growth in numerous malignant cell types, suggesting that PPAR- $\gamma$ agonists may act as tumor suppressors (4). PPAR- $\gamma$ is a transcription factor that participates in metabolism of lipid and glucose (5). PPAR- $\gamma$ is expressed at a high level in adipose tissue, regulating adipocyte differentiation and glucose utilization (6). PPAR $-\gamma$ is also expressed in intestinal epithelial cells and tumor cells in breast, colon, and lung (7-10). In addition, reduction of the expression levels of PPAR- $\gamma$ in PPAR $-\gamma^{+/-}$mice is associated with an increased susceptibility to 7,12-dimethylbenz(a) anthracene-mediated carcinogenesis in the skin (11). A previous study indicated that topical treatment of hairless mice with PPAR- $\gamma$ agonists troglitazone and ciglitazone enhanced the expression of markers of differentiation that promoted epidermal barrier recovery (12).

Tumors may be caused by a number of factors, including genetic mutations that lead to malfunction of the cell cycle, inhibition of apoptosis and environmental factors that lead to DNA damage (13). Clinically, the induction of apoptosis to modulate cell growth has become an important approach in cancer therapy (14). To examine the function and mechanism of PPAR- $\gamma$ agonist in treating malignant skin cancer, the present study investigated the effect of one of the most potent PPAR- $\gamma$ agonists, rosiglitazone, on cell growth and cell apoptosis in vitro. It was identified that rosiglitazone inhibited cell growth, potentially through reducing the expression of cell cycle-associated proteins and without affecting apoptosis.

\section{Materials and methods}

Cell culture experiment. Human epidermoid carcinoma A431 cells (American Type Culture Collection, Manassas, VA, USA) 
were cultured in Dulbecco's modified Eagle's medium/Ham's (powder, high glucose; cat no. 12800017; Gibco; Thermo Fisher Scientific, Inc., Waltham, MA, USA) supplemented with $0.15 \%$ sodium bicarbonate, $10 \%$ fetal bovine serum and $100 \mathrm{U} / \mathrm{ml}$ penicillin-streptomycin (all from Invitrogen; Thermo Fisher Scientific, Inc.) at $37^{\circ} \mathrm{C}$ under $5 \% \mathrm{CO}_{2}$. The stock solution of rosiglitazone (Sigma-Aldrich; Merck KGaA, Darmstadt, Germany) was dissolved in dimethyl sulfoxide (DMSO; Cell Signaling Technology, Inc., Danvers, MA, USA). For all drug assays, an equal amount of DMSO was added as a control.

MTS assay. Cell viability was evaluated using MTS assay (Promega Corporation, Madison, WI, USA). Specifically, 5,000 A431 cells were seeded in each well of a 96-well plate and incubated with different concentrations of rosiglitazone $(0,10,20,30,40$ and $100 \mu \mathrm{M})$ for $24 \mathrm{~h}$ at $37^{\circ} \mathrm{C}$. Then, $20 \mu \mathrm{l}$ MTS/well was added and incubated at room temperature for $4 \mathrm{~h}$. Cell viability was measured by absorbance at $490 \mathrm{~nm}$ using a microplate reader.

${ }^{3} H$-Thymidine incorporation assay. A431 cells (density, $5 \times 10^{4}$ cells/well) were seeded on 6 -well plates and cells at $80 \%$ confluence were treated in triplicate with vehicle or rosiglitazone $(10,20,30$ and $40 \mu \mathrm{M})$ for $3-24 \mathrm{~h}$ at $37^{\circ} \mathrm{C}$. A total of $2 \mathrm{~h}$ prior to harvesting, cells were pulsed with $1 \mu \mathrm{C} 1 \mathrm{mCi} / \mathrm{ml}$ ${ }^{3} \mathrm{H}$-thymidine (Merck KGaA) at $37^{\circ} \mathrm{C}$ for $30 \mathrm{~min}$. At each time point of harvesting, cells were washed with cold PBS buffer, and then fixed with cold $10 \%$ (w/v) trichloroacetic acid (three times; firstly for $10 \mathrm{~min}$, then 5 min twice). Next, cell lysis was performed at room temperature by adding $1 \mathrm{ml}$ lysis buffer $(0.3 \mathrm{~N} \mathrm{NaOH}, 1 \% \mathrm{SDS})$ for $15 \mathrm{~min}$. Following cell lysis, the lysates were transferred to scintillation vials, then mixed with $5 \mathrm{ml}$ scintillation liquid to measure radioactivity, which was later normalized to protein concentration (15).

Flow cytometric analysis of cell cycle and apoptosis. A431 cells (density, $5 \times 10^{4}$ cells/well) were seeded on 6-well plates and, at $80 \%$ confluence, cells were treated with the rosiglitazone $(10,20,30$ and $40 \mu \mathrm{M})$ for $24 \mathrm{~h}$ at $37^{\circ} \mathrm{C}$. For cell cycle analysis, cells were fixed at $4^{\circ} \mathrm{C}$ with $70 \%$ ethanol overnight and stained with $500 \mu \mathrm{l}$ propidium iodide (PI; $40 \mathrm{mg} / \mathrm{ml}$ ) at room temperature for $30 \mathrm{~min}$, then analyzed by flow cytometry (BD FACSAria Cell Sorter; BD Biosciences, Franklin Lakes, NJ, USA). For apoptosis analysis, harvested cells were resuspended in $400 \mu \mathrm{l}$ binding buffer (with $\mathrm{Ca}^{2+}$; Thermo Fisher Scientific, Inc.) and divided into two tubes; one was used as the blank group and the second one was incubated with $5 \mu \mathrm{l}$ Annexin $\mathrm{V}$ in the dark for $15 \mathrm{~min}$ at room temperature. A total of $10 \mu \mathrm{l}$ PI was then added and apoptosis was analyzed by flow cytometry (excitation, $488 \mathrm{~nm}$; emission, $515 \mathrm{~nm}$ ). Untreated cells were used as an additional control in addition to the DMSO control group.

Western blot analysis. A431 cells (density, 5x104 cells/well) were seeded on 6-well plates and, at $80 \%$ confluence, cells were treated with drugs $[40 \mu \mathrm{M}$ rosiglitazone or $10 \mu \mathrm{M}$ GW9662 (Tocris Bioscience, Bristol, UK)] or transfected with PPAR- $\gamma$ small interfering (si)RNAs according to a previous study (16). Then, the cells were harvested following treatment for $24 \mathrm{~h}$. Total cellular proteins were extracted with radioimmunoprecipitation lysis buffer (Cell Signaling Technology, Inc.) and protein concentration was measured with the BCA Assay kit (Shanghai Shenergy Biocolor Bioscience and Technology Company, Shanghai, China). Protein samples (20-40 $\mu \mathrm{g}$ ) were separated on 8-12\% SDS-PAGE gels and then transferred onto $0.22 \mu \mathrm{m}$ polyvinylidene fluoride membranes. Subsequent to blocking for $1 \mathrm{~h}$ at room temperature with $5 \%$ non-fat milk or BSA in Tris-buffered saline with $0.1 \%$ Tween-20, membranes were incubated with primary antibodies against B-cell lymphoma 2 (Bcl-2; cat no. 15071; 1:1,000), Bcl-2 associated X protein (Bax; cat no. 2274; 1:1,000), cyclin D1 (cat no. 2922; 1:1,000), cyclin-dependent kinase [(Cdk)2; cat no. 2546; 1:1,000)], Cdk4 (cat no. 12790; 1:1,000), and GAPDH (cat no. 5174; 1:1,000) (all from Cell Signaling Technology, Inc.) overnight at $4{ }^{\circ} \mathrm{C}$. Following washing in Tris-buffered saline with $0.1 \%$ Tween-20 4 times for 5 min each, membranes were incubated with horseradish peroxidase (HRP)-conjugated secondary antibodies (HRP-conjugated rabbit anti-mouse immunoglobulin G, cat no. ab6728 or HRP-conjugated goat anti-rabbit immunoglobulin G; cat no. ab6721) (both secondary antibodies from Abcam, Cambridge, MA, USA; dilution, 1:5,000) for $1 \mathrm{~h}$ at room temperature. Western blot membranes were developed using Immobilon ${ }^{\mathrm{TM}}$ Western Chemiluminescent HRP substrate (EMD Millipore, Billerica, MA, USA), analyzed with Gel Documentation and Analysis system (G-Box, Syngene Europe, Cambridge, UK). The density of the protein of interest was normalized to GAPDH with ImageJ (version 1.46; National Institutes of Health, Bethesda, MD, USA).

Statistical analysis. Data were calculated and expressed as the mean \pm standard deviation, unless otherwise specified. For semi-quantitative western blot analysis, the data were presented as the mean \pm standard error of the mean. To decrease the variance in analysis, 3 sets of samples were collected from independent experiments and triplicate western blot experiments were performed for each set of samples. The mean of each set of samples and the standard error of the mean of all 3 sets of samples were then calculated and expressed. For the results of the ${ }^{3} \mathrm{H}$-Thymidine incorporation assay in Fig. 2, differences among distinct groups were analyzed by two-way analysis of variance (ANOVA), in order to examine the effects of treatment time and drug doses. If there was a significant interaction, post hoc analysis was performed using Dunnett's test to compare each group. For the data of the MTS assay, flow cytometry analysis and semi-quantitative western blot analysis, one-way ANOVA was used to analyze the effects of different treatment followed by Dunnett's test if there was a significant interaction. $\mathrm{P}<0.05$ was considered to indicate a statistically significant difference. All analyses were performed using SPSS 13.0 statistical software (SPSS, Inc., Chicago, IL, USA).

\section{Results}

Rosiglitazone inhibits cell proliferation. To determine the tolerated treatment concentration of rosiglitazone, cell viability in response to different doses of rosiglitazone was primarily examined. As demonstrated in Fig. 1, at a lower concentration of rosiglitazone $(\leq 40 \mu \mathrm{M})$, no significant effect 


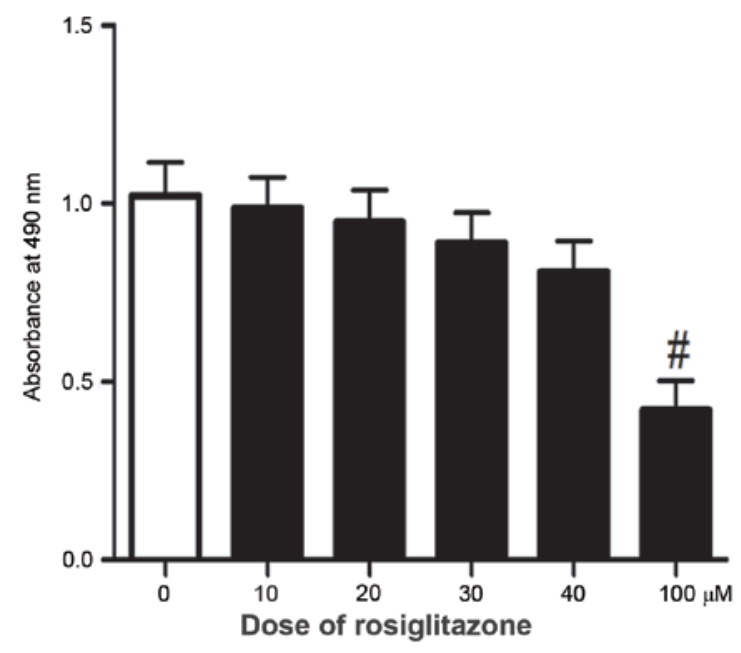

Figure 1. MTS assay of A431 cell viability. A431 cells were incubated with different concentrations $(0-100 \mu \mathrm{M})$ rosiglitazone for $24 \mathrm{~h}$. Cell viability was determined by MTS assay kit. Data are presented as the mean \pm standard deviation of three independent experiments. ${ }^{~} \mathrm{P}<0.05(0 \mu \mathrm{M}$ rosiglitazone vs. $100 \mu \mathrm{M}$ rosiglitazone) as analyzed with one-way analysis of variance.

on cell viability was observed. With higher concentrations (60 and $80 \mu \mathrm{M})$ of rosiglitazone, a decreased but not significant effect on cell viability (data not shown) was observed. However, there was a significant inhibition on cell viability with $100 \mu \mathrm{M}$ rosiglitazone. It has been demonstrated that a high concentration of rosiglitazone exhibits side effects on normal skin cells (17). Considering the potential drug safety issue for treatment, the experiments of the present study were limited to low concentrations of rosiglitazone, $<40 \mu \mathrm{M}$, to maintain the effect of rosiglitazone on cell viability at a low level. Firstly, to investigate the anticancer potential of rosiglitazone in human epidermoid carcinoma, the effects of rosiglitazone on A431 cell proliferation were evaluated. A431 cells were cultured in Dulbecco's Modified Eagle's Medium for $24 \mathrm{~h}$ prior to stimulation with rosiglitazone for 3-24 h. A ${ }^{3} \mathrm{H}$-thymidine incorporation assay was then performed to evaluate cell proliferation. As demonstrated in Fig. 2, at the lowest concentration and as early as $3 \mathrm{~h}$ after treatment, rosiglitazone inhibited DNA synthesis and cell proliferation markedly. This inhibitory effect was dose- and time-dependent, with higher concentrations of rosiglitazone and longer treatment times resulting in increased inhibitory effects.

Rosiglitazone inhibits cell cycle progression. As rosiglitazone suppressed DNA synthesis and cell proliferation, the present study sought to examine which step of cell cycle was affected. A431 cells were treated with different concentrations (10-40 $\mu \mathrm{M})$ of rosiglitazone for $24 \mathrm{~h}$. Then, the cell cycle was analyzed with flow cytometry. In Fig. 3, it was identified that with increasing concentration of rosiglitazone, the ratio of number of cells at G1 to number of cells at G0 phase increased, and the number of cells at $\mathrm{S}$ phase decreased, indicating that rosiglitazone inhibited cell cycle progression from G1 to $\mathrm{S}$ phase.

Rosiglitazone exhibits no significant effect on cell apoptosis. The present study investigated whether there was any

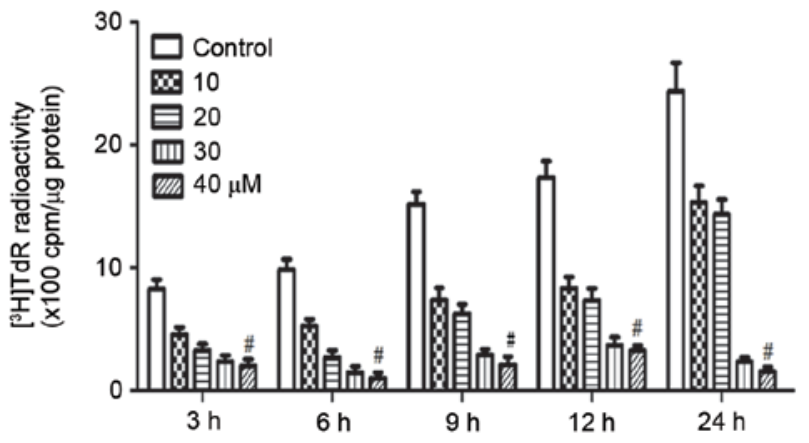

Figure 2. Effect of rosiglitazone on A431 cell proliferation. A431 cells treated with different concentrations of rosiglitazone were pulsed with ${ }^{3} \mathrm{H}$ thymidine and harvested at different time points (3, 6, 9, 12 and $24 \mathrm{~h})$. DNA synthesis activity was quantified by ${ }^{3} \mathrm{H}$ thymidine incorporation assay. The data from three independent experiments are presented as mean \pm standard deviation. ${ }^{\#} \mathrm{P}<0.05$ (vs. control for each time point) as analyzed with two-way analysis of variance. $\left[{ }^{3} \mathrm{H}\right] \mathrm{T},{ }^{3} \mathrm{H}$ thymidine; cpm, counts per minute.

association between inhibition of cell proliferation and apoptosis. The effect of rosiglitazone on cell apoptosis in A431 cells was examined by flow cytometry with Annexin V, a marker for apoptosis, and PI, a DNA stain to evaluate cell viability. As indicated in Fig. 4, with the increasing concentration of rosiglitazone, no effect on the distribution of A431 cells in the upper right and lower right regions was observed, indicating that there was no increase in apoptosis due to rosiglitazone treatment.

Rosiglitazone regulates cell cycle-associated protein expression. To additionally understand how rosiglitazone regulates cell proliferation, the protein expression levels of cell cycle-associated proteins, including CyclinD1, Cdk2 and Cdk4 were examined. Notably, it was identified that the expression levels of these proteins decreased as the concentration of rosiglitazone increased (Fig. 5A). However, rosiglitazone exhibited no effects on the regulation of the ratio of Bcl-2 to Bax, which is an indicator of cell apoptosis. In addition, whether rosiglitazone regulated protein expression levels of cyclin D1, Cdk2 and Cdk4 through PPAR- $\gamma$ was examined. Firstly, a selective antagonist (GW9662) was used to inhibit PPAR- $\gamma$, and it was identified that this inhibitor rescued the agonistic effects of rosiglitazone on the modulation of expression levels of cyclin D1, Cdk2 and Cdk4 (Fig. 5B). Secondly, specific knockdown of PPAR- $\gamma$ also rescued the expression levels of cyclin D1, Cdk2, Cdk4 in cells treated with rosiglitazone (Fig. 5B). However, these manipulations did not affect the expression ratio of $\mathrm{Bcl}-2$ to Bax. Taken together, these results suggest that rosiglitazone may downregulate protein expression levels of cyclin D1, Cdk2 and Cdk4 to suppress cell cycle progress through PPAR- $\gamma$.

\section{Discussion}

PPAR- $\gamma$ is known to be associated with the development of malignancies in the breasts, colon and pancreas; however, its effects on tumor proliferation vary in different types of cancer (18-24). Previously, multiple studies have indicated that activating PPAR- $\gamma$ inhibits cell growth through arrest of the cell cycle and induction of apoptosis (25-27). In the present study, the effect of PPAR- $\gamma$ agonist, rosiglitazone, on 

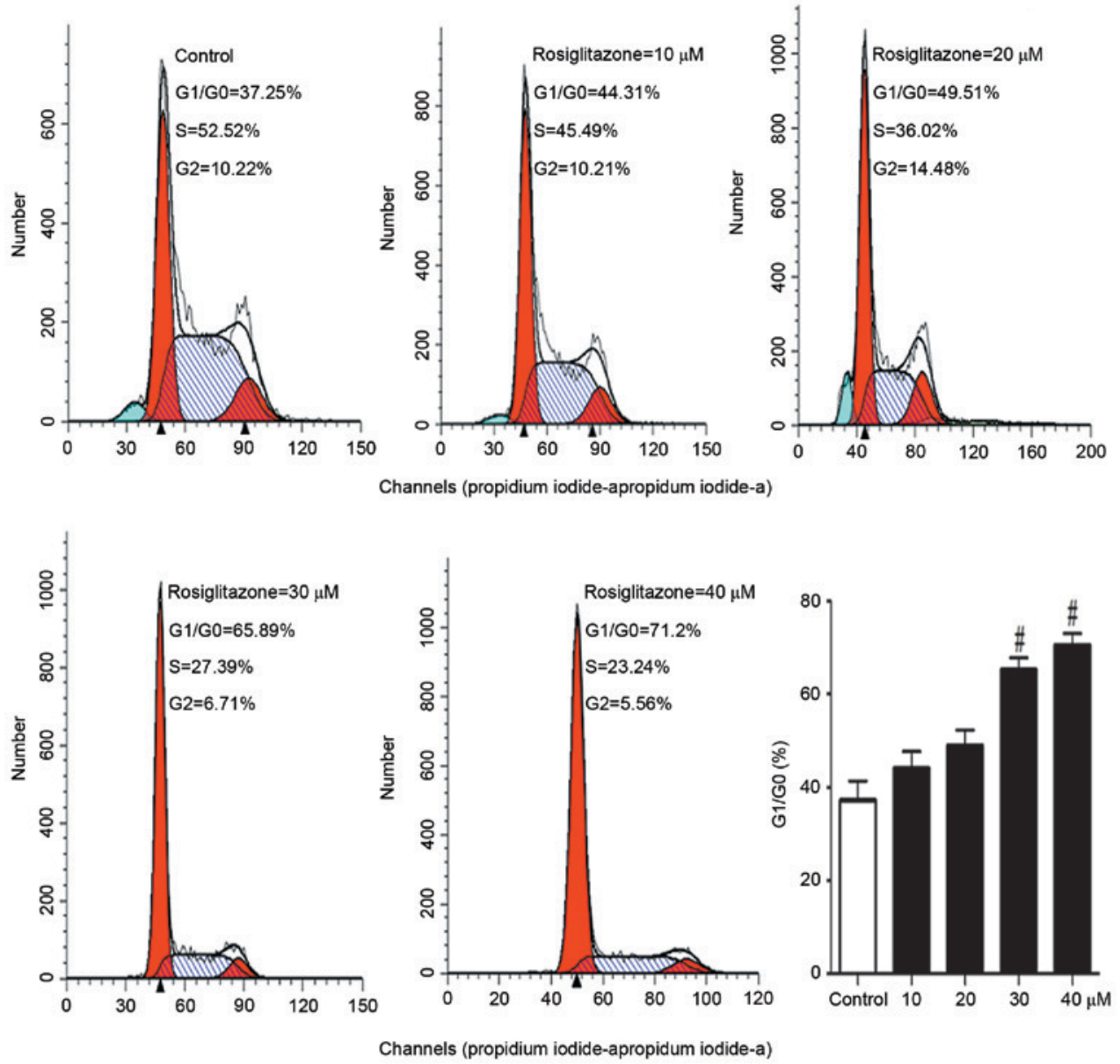

Figure 3. Cell cycle arrest induced by rosiglitazone. A431 cells at $80 \%$ confluence were stimulated with rosiglitazone for $24 \mathrm{~h}$. Propidium iodide stained single-cell suspensions were obtained and DNA content was analyzed by flow cytometry. The first red peak around 50 represents G1/G0 phase cells. The middle, shaded peak represents S phase cells. The second red peak, around 90, represents G2 phase cells. Data from three independent experiments are collected and the average G1/G0 percentage is presented in the bar graph. ${ }^{\prime \prime} \mathrm{P}<0.05$ (vs. control).
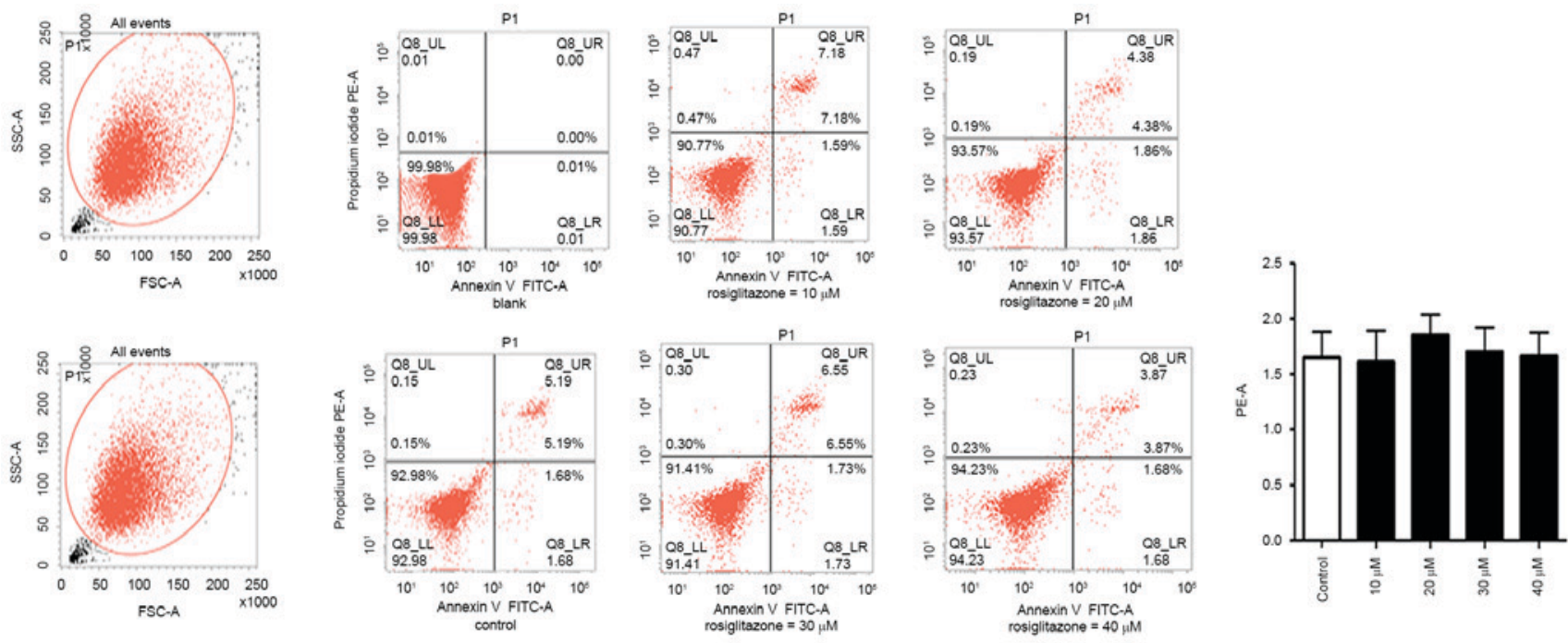

Figure 4. Effect of rosiglitazone on A431 cell apoptosis. A431 cells at $80 \%$ confluence were stimulated with rosiglitazone for 24 h. Propidium iodide stained single-cell suspensions were obtained, and cell apoptosis analyses were performed by flow cytometry. A set of representative graphs from three independent experiments is presented. The average apoptotic cells were presented in the bar plot, and there was no significant difference among distinct treatments observed.

the human epidermoid carcinoma A431 cell line was investigated. The results demonstrated that rosiglitazone exerted an inhibitory effect on cell proliferation through inhibiting progression from $\mathrm{G} 1$ to $\mathrm{S}$ phase in cell cycle. However, rosiglitazone did not induce apoptosis. Consistent with this, there was a significant reduction in cyclin D1, Cdk2 and Cdk4 

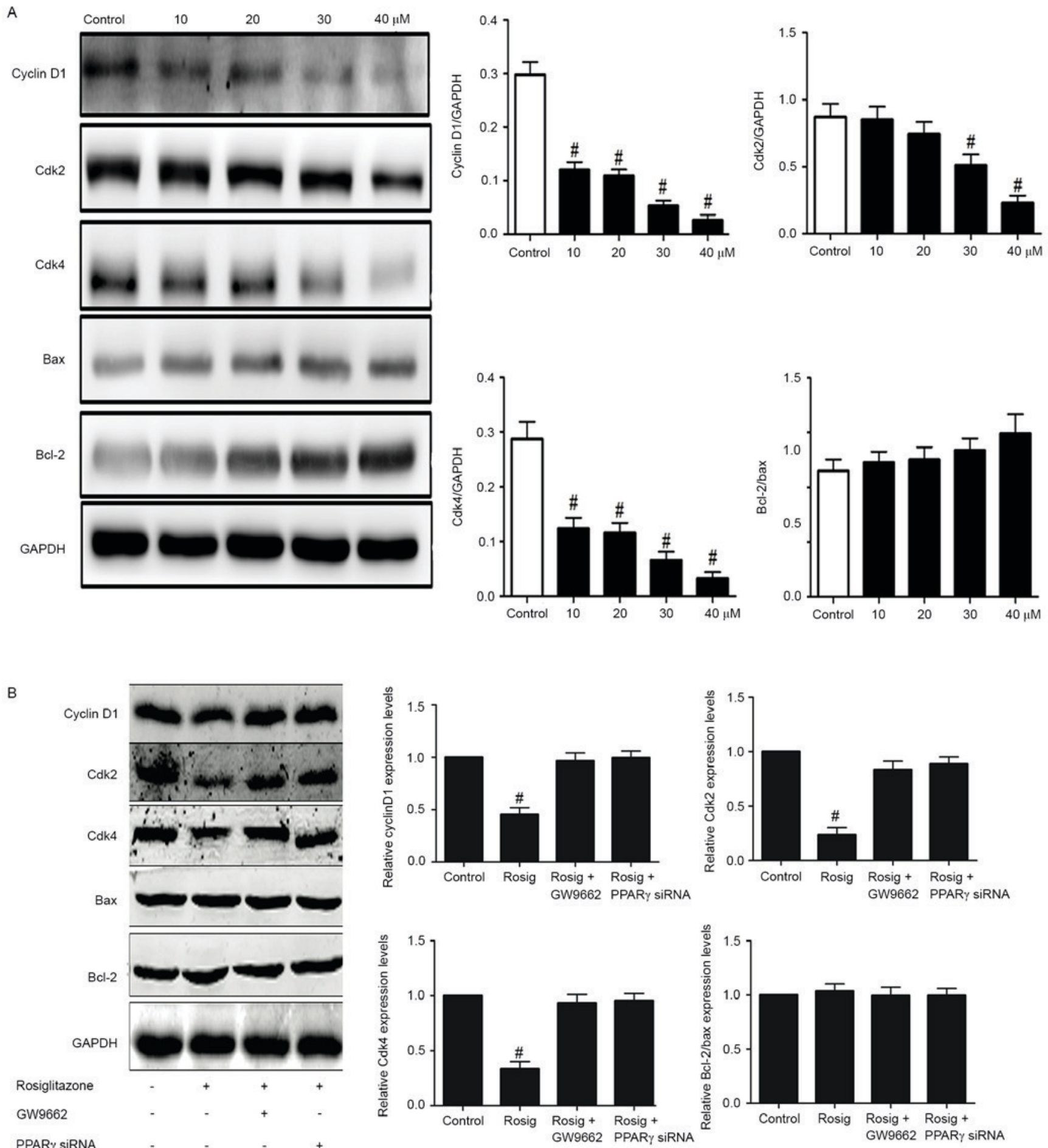

Figure 5. Effect of rosiglitazone on the protein level of cell cycle- and apoptosis-associated proteins. (A) A431 cells at $80 \%$ confluence were stimulated with rosiglitazone for $24 \mathrm{~h}$, and the effects on Bax, Bcl-2, cyclin D1, cdk2 and cdk4 expression were analyzed by western blotting. Data were quantified by scanning densitometry, and the ratio of the protein of interest was normalized to GAPDH. Data are presented as means $\pm \mathrm{SEM}(\mathrm{n}=3)$. $\mathrm{P}<0.05(10,20,30$, $40 \mathrm{mM}$ rosiglitazone treatment compared with control treatment for cyclin D1/GAPDH and Cdk4/GAPDH; 30, $40 \mathrm{mM}$ rosiglitazone treatment compared with control treatment for Cdk2/GAPDH) as analyzed with one-way ANOVA. (B) A431 cells at 80\% confluence were stimulated with rosiglitazone or GW9662 or transfected with PPAR- $\gamma$ siRNAs for $24 \mathrm{~h}$ and the effects on Bax, Bcl-2, cyclin D1, cdk2 and cdk4 expression were analyzed by western blotting. Data were quantified by scanning densitometry and the ratio of the protein of interest was normalized to GAPDH. Data are presented as means \pm SEM ( $=3$ ). ${ }^{\#} \mathrm{P}<0.05$ (rosiglitazone vs. control; rosiglitazone vs. rosiglitazone plus GW9662; rosiglitazone vs. rosiglitazone plus PPAR- $\gamma$ siRNAs for cyclin D1/GAPDH, Cdk2/GAPDH and Cdk4/GAPDH) as analyzed with one-way ANOVA. ANOVA, analysis of variance; SEM, standard error of the mean; siRNA, small interfering RNA; Cdk, cyclin-dependent kinase; Bcl-2, B-cell lymphoma 2; Bax, Bcl-2 associated X protein; Rosig, rosiglitazone; PPAR- $\gamma$, peroxisome proliferator-activated receptor- $\gamma$.

protein levels. Furthermore, this reduction was rescued with a PPAR- $\gamma$ antagonist or PPAR- $\gamma$ agonist siRNAs. Therefore, these results suggest that the inhibitory effects of rosiglitazone on cell proliferation are mediated by downregulation 
of cyclin D1, Cdk2 and Cdk4 expression through the activation of PPAR- $\gamma$.

Increased DNA synthesis activity was observed in control cells at $9 \mathrm{~h}$. Therefore, the present study hypothesized that following rosiglitazone activation, quiescent cells re-entered the cell cycle. However, DNA synthesis activity was similar between 6 and $3 \mathrm{~h}$ in the control cells, suggesting that at least $6 \mathrm{~h}$ was required for these quiescent cells to reach the $\mathrm{S}$ phase. At an early time-point, for example $3 \mathrm{~h}$, rosiglitazone markedly inhibited DNA synthesis. Therefore, the present study suggested that rosiglitazone inhibits cell proliferation through inhibiting dividing cells entering into $\mathrm{S}$ phase at an early time point.

Notably, rosiglitazone exhibited no effects on the Bcl-2/Bax ratio, suggesting that apoptosis is not implicated in the inhibitory effects of rosiglitazone. Flow cytometry data also supported this observation, indicating that there was no difference between the control and treated groups in apoptosis. Previous studies have demonstrated evidence that PPAR $-\gamma$ serves important roles in anti-apoptotic pathways (12-14). In concordance with this, the present data support that PPAR- $\gamma$ agonists inhibit cell proliferation independent of the induction of apoptosis. However, the effects of PPAR- $\gamma$ agonists on the human epidermoid carcinoma cells require additional investigation in vivo.

To conclude, the present study suggested evidence that PPAR- $\gamma$ agonists are implicated in the regulation of cell growth in human epidermoid carcinoma cells. Rosiglitazone inhibited cell proliferation of human epidermoid carcinoma. This inhibitory effect involved the regulation of the expression of cell cycle-associated proteins, but was independent of apoptosis. These results provide novel insights into rosiglitazone and the development of anticancer therapies for epidermoid carcinoma. However, additional studies are required to improve the understanding of the molecular and cellular mechanisms of this potential anticancer drug. For example, it may be useful to further investigate the mechanisms of inhibition of cell proliferation by PPAR- $\gamma$ agonists, and identify essential factors involved in the modulation of cyclin D1, Ckd2 and Cdk4 expression that contribute to the regulation of cell cycle arrest. Previously, a study demonstrated that rosiglitazone activated G protein coupled receptor 40 , additionally regulating the PPAR- $\gamma$ pathway (28). The present study may suggest a potential underlying mechanism of how rosiglitazone activates PPAR- $\gamma$ to regulate the cell cycle. Furthermore, it is necessary to investigate the effects of PPAR- $\gamma$ agonists in animal models, to confirm the data gathered in vitro. The present study aimed to contribute to developing effective anticancer therapies by understanding the cellular and molecular mechanisms of potential drugs.

\section{Acknowledgements}

The present study was partly supported by the National Natural Science Foundation of China (grant nos. 81100101 and 81270212).

\section{References}

1. Sauter ER, Herlyn M, Liu SC, Litwin S and Ridge JA: Prolonged response to antisense cyclin D1 in a human squamous cancer xenograft model. Clin Cancer Res 6: 654-660, 2000.
2. Trakatelli M,Ulrich C, del Marmol V, Euvrard S, Stockfleth E and Abeni D: Epidemiology of nonmelanoma skin cancer (NMSC) in Europe: Accurate and comparable data are needed for effective public health monitoring and interventions. Br J Dermatol 156 (Suppl 3): S1-S7, 2007.

3. Karia PS, Han J and Schmults CD: Cutaneous squamous cell carcinoma: Estimated incidence of disease, nodal metastasis, and deaths from disease in the United States, 2012. J Am Acad Dermatol 68: 957-966, 2013.

4. Dong JT: Anticancer activities of PPAR $\gamma$ in breast cancer are context-dependent. Am J Pathol 182: 1972-1975, 2013.

5. Issemann I and Green S: Activation of a member of the steroid hormone receptor superfamily by peroxisome proliferators. Nature 347: 645-650, 1990

6. Kersten S, Desvergne B and Wahli W: Roles of PPARs in health and disease. Nature 405: 421-424, 2000.

7. Elstner E, Müller C, Koshizuka K, Williamson EA, Park D, Asou H, Shintaku P, Said JW, Heber D and Koeffler HP: Ligands for peroxisome proliferator-activated receptorgamma and retinoic acid receptor inhibit growth and induce apoptosis of human breast cancer cells in vitro and in BNX mice. Proc Natl Acad Sci USA 95: 8806-8811, 1998.

8. Sarraf P, Mueller E, Jones D, King FJ, DeAngelo DJ, Partridge JB, Holden SA, Chen LB, Singer S, Fletcher C and Spiegelman BM: Differentiation and reversal of malignant changes in colon cancer through PPARgamma. Nat Med 4: 1046-1052, 1998.

9. Motomura W, Okumura T, Takahashi N, Obara T and Kohgo Y: Activation of peroxisome proliferator-activated receptor gamma by troglitazone inhibits cell growth through the increase of p27KiP1 in human. Pancreatic carcinoma cells. Cancer Res 60: 5558-5564, 2000.

10. Inoue K, Kawahito Y, Tsubouchi Y, Kohno M, Yoshimura R, Yoshikawa T and Sano H: Expression of peroxisome proliferator-activated receptor gamma in renal cell carcinoma and growth inhibition by its agonists. Biochem Biophys Res Commun 287: 727-732, 2001.

11. Nicol CJ, Yoon M, Ward JM, Yamashita M, Fukamachi K, Peters JM and Gonzalez FJ: PPARgamma influences susceptibility to DMBA-induced mammary, ovarian and skin carcinogenesis. Carcinogenesis 25: 1747-1755, 2004.

12. Mao-Qiang M, Fowler AJ, Schmuth M, Lau P, Chang S, Brown BE, Moser AH, Michalik L, Desvergne B, Wahli W, et al: Peroxisome-proliferator-activated receptor (PPAR)-gamma activation stimulates keratinocyte differentiation. J Invest Dermatol 123: 305-312, 2004.

13. Kundoor V, Zhang X, Bommareddy A, Khalifa S, Fahmy H and Dwivedi C: Chemopreventive effects of sarcotriol on ultraviolet B-induced skin tumor development in SKH-1 hairless mice. Mar Drugs 5: 197-207, 2007.

14. Sarfaraz S, Adhami VM, Syed DN, Afaq F and Mukhtar H: Cannabinoids for cancer treatment: Progress and promise. Cancer Res 68: 339-342, 2008.

15. He G, Thuillier P and Fischer SM: Troglitazone inhibits cyclin D1 expression and cell cycling independently of PPARgamma in normal mouse skin keratinocytes. J Invest Dermatol 123: 1110-1119, 2004

16. Chen Z, He P, Ding X, Huang Y, Gu H and Ni X: PPAR $\gamma$ stimulates expression of L-type amino acid and taurine transporters in human placentas: The evidence of PPAR $\gamma$ regulating fetal growth. Sci Rep 5: 12650, 2015.

17. Wu M, Melichian DS, Chang E, Warner-Blankenship M, Ghosh AK and Varga J: Rosiglitazone abrogates bleomycin-induced scleroderma and blocks profibrotic responses through peroxisome proliferator-activated receptor-gamma. Am J Pathol 174: 519-533, 2009.

18. Mueller E, Sarraf P, Tontonoz P, Evans RM, Martin KJ, Zhang M, Fletcher C, Singer S and Spiegelman BM: Terminal differentiation of human breast cancer through PPAR gamma. Mol Cell 1: 465-470, 1998.

19. Jiang WG, Redfern A, Bryce RP and Mansel RE: Peroxisome proliferator activated receptor-gamma (PPAR-gamma) mediates the action of gamma linolenic acid in breast cancer cells. Prostaglandins Leukot Essent Fatty Acids 62: 119-127, 2000.

20. Youssef J and Badr M: Peroxisome proliferator-activated receptors and cancer: Challenges and opportunities. Br J Pharmacol 164: 68-82, 2011.

21. Kitamura S, Miyazaki Y, Shinomura Y, Kondo S, Kanayama S and Matsuzawa Y: Peroxisome proliferator-activated receptor gamma induces growth arrest and differentiation markers of human colon cancer cells. Jpn J Cancer Res 90: 75-80, 1999. 
22. Tsujie M, Nakamori S, Okami J, Hayashi N, Hiraoka N, Nagano H, Dono K, Umeshita K, Sakon M and Monden M: Thiazolidinediones inhibit growth of gastrointestinal, biliary, and pancreatic adenocarcinoma cells through activation of the peroxisome proliferator-activated receptor gamma/retinoid X receptor alpha pathway. Exp Cell Res 289: 143-151, 2003.

23. Itami A, Watanabe G, Shimada Y, Hashimoto Y, Kawamura J, Kato M, Hosotani R and Imamura M: Ligands for peroxisome proliferator-activated receptor gamma inhibit growth of pancreatic cancers both in vitro and in vivo. Int J Cancer 94: 370-376, 2001.

24. Kawa S, Nikaido T, Unno H, Usuda N, Nakayama $\mathrm{K}$ and Kiyosawa K: Growth inhibition and differentiation of pancreatic cancer cell lines by PPAR gamma ligand troglitazone. Pancreas 24: 1-7, 2002.

25. Altiok S, Xu M and Spiegelman BM: PPARgamma induces cell cycle withdrawal: Inhibition of E2F/DP DNA-binding activity via down-regulation of PP2A. Genes Dev 11: 1987-1998, 1997.
26. Ramachandran L, Manu KA, Shanmugam MK, Li F, Siveen KS Vali S, Kapoor S, Abbasi T, Surana R, Smoot DT, et al: Isorhamnetin inhibits proliferation and invasion and induces apoptosis through the modulation of peroxisome proliferator-activated receptor $\gamma$ activation pathway in gastric cancer. J Biol Chem 287: 38028-38040, 2012.

27. Lee NJ, Oh JH, Ban JO, Shim JH, Lee HP, Jung JK, Ahn BW, Yoon DY, Han SB, Ham YW and Hong JT: 4-O-methylhonokiol, a PPAR $\gamma$ agonist, inhibits prostate tumour growth: p21-mediated suppression of NF- $\kappa$ B activity. Br J Pharmacol 168: 1133-1145, 2013.

28. Wang S, Awad KS, Elinoff JM, Dougherty EJ, Ferreyra GA, Wang JY, Cai R, Sun J, Ptasinska A and Danner RL: G protein-coupled receptor 40 (GPR40) and peroxisome proliferator-activated receptor $\gamma$ (PPAR $\gamma)$ : AN integrated two-receptor signaling pathway. J Biol Chem 290: 19544-19557, 2015. 